\title{
UJI AKTIVITAS ANTIBAKTERI EKSTRAK ETANOL 96\% UMBI BAWANG SUNA (Allium schoenoprasum L.) TERHADAP PERTUMBUHAN Staphylococcus aureus DAN Staphylococcus saprophyticus DENGAN METODE DIFUSI CAKRAM KIRBY-BAUER
}

\author{
Putri Hagalang Sinta ${ }^{1}$, Dewi Klarita Furtuna ${ }^{2}$ dan Fatmaria ${ }^{3}$ \\ 1. Program Studi Pendidikan Dokter, Fakultas Kedokteran, Universitas Palangka Raya, Palangka Raya, Indonesia \\ ${ }^{2.3}$ Staff Pengajar Fakultas Kedokteran, Universitas Palangka Raya, Palangka Raya, Indonesia \\ Email: hagalangsintaputri@yahoo.co.id
}

\begin{abstract}
Background: Urinary tract infection (UTI) are one of the most frequent clinical bacterial infections in women and men of all ages with various clinical manifestation and episodes caused by bacterial-like microorganisms. Suna onion bulbs (Allium schoenoprasum L), one of Kalimantan Tengah medicine plan, often use in society as culinary additives and also as traditional medicine. This study aims to analyse antibacterial activity of ethanol $96 \%$ extract of Suna onion bulbs again to Staphylococcus aureus and Staphylococcus saprophyticus with Kirby-Bauer disc diffusion method.

Method: This research was a true experimental design with extract concentration were: $100 \%, 80 \%, 60 \%, 40 \%$ and $20 \%$, as positive control use azithromycin.

Result : The significance value obtained from the Kruskal Wallis test on Staphylococcus aureus data is 0.001 and Staphylococcus saprophyticus data is $<0.001(p<0.05)$ it means that there is a difference between concentration in extract suna onion bulb.

Conclusion: Suna onion bulbs extract can inhibit the growth of Staphylococcus aureus and Staphylococcus saprophyticus.
\end{abstract}

Key words: Allium schoenoprasum L, UTI, antibacterial, Staphylococcus aureus, Staphylococcus saprophyticus.

\section{ABSTRAK}

Pendahuluan: Pendahuluan: Infeksi Saluran Kemih (ISK) merupakan salah satu masalah kesehatan yang sering menyerang pria dan wanita dari segala usia dengan berbagai gambaran klinis dan episode yang disebabkan oleh mikroorganisme seperti bakteri. Umbi bawang suna (Allium schoenoprasum L) merupakan salah satu tanaman yang digunakan oleh masyarakat Kalimantan Tengah sebagai bumbu dapur tetapi juga sebagai obat tradisional. Penelitian ini bertujuan untuk mengetahui pengaruh potensi ekstrak etanol $96 \%$ umbi bawang suna (Allium schoenoprasum L) dalam menghambat pertumbuhan bakteri Staphylococcus aureus dan Staphylococcus saprophyticus dengan metode difusi cakram Kirby-Bauer.

Metode: Penelitian ini menggunakan true experimental design dengan variasi konsentrasi ekstrak yang digunakan $100 \%, 80 \%, 60 \%$, 40\%, dan 20\% serta kontrol positif Azitromisin.

Hasil: Berdasarkan hasil uji Kruskal Wallis nilai signifikansi yang diperoleh untuk bakteri Staphylococcus aureus ialah 0.001 dan Staphylococcus saprophyticus $<0.001(\mathrm{p}<0.05)$ yang berarti hipotesis diterima (terdapat perbedaan bermakna).

Simpulan: Ekstrak etanol 96\% umbi bawang suna (Allium schoenorasum L) mempunyai daya hambat terhadap pertumbuhan bakteri Staphylococcus aureus dan Staphylococcus saprophyticus.

Kata kunci : Allium schoenoprasum L, ISK, antibakteri, Staphylococcus aureus, Staphylococcus saprophyticus. 


\section{PENDAHULUAN}

Infeksi Saluran Kemih (ISK) merupakan salah satu masalah kesehatan yang sering menyerang pria dan wanita dari segala usia dengan berbagai gambaran klinis dan episode. ${ }^{1}$ Berdasarkan National Kidney and Urologic Diseases Information Clearinghouse (NKUDIC) ISK menempati urutan kedua setelah infeksi saluran nafas atas (ISPA) yaitu sebanyak 8.3 juta kasus dilaporkan setiap tahun. ${ }^{2}$ Terdapat kunjungan ke rumah sakit sebanyak 10.5 juta atau hampir seperlima (21.3\%) pasien dengan gejala ISK pada tahun 2007 di Amerika Serikat. ${ }^{3}$ Di Indonesia prevalensi ISK mencapai 90-100 kasus per 100,000 penduduk per tahun atau 180,000 kasus baru pertahun. ${ }^{4}$ Berdasarkan data bagian Instalasi Rekam Medik RSUD dr Doris Sylvanus menunjukkan jumlah pasien ISK rawat inap pada tahun 2014-2018 mencapai 912 orang. ${ }^{5}$ ISK umumnya lebih sering pada wanita daripada pria dengan perbandingan 30:1. Sekitar $50 \%$ ISK pada wanita akan berkembang menjadi ISK berulang. Pada bayi dan anak sekolah insiden ISK berkisar $1-2 \%$, pada wanita muda yang tidak hamil 1$3 \%$, sedangkan pada wanita yang hamil $4-7 \%{ }^{6}$

Infeksi Saluran Kemih (ISK) adalah kondisi dimana terdapat mikroorganisme dalam urin yang jumlahnya sangat banyak sehingga menimbulkan infeksi pada saluran kemih. Uromukoid atau protein Tamm-Horsfall (THP) merupakan protein bakterisidal di dalam urine yang bekerja dengan cara mencegah bakteri menempel pada urotelium. Akan tetapi, protein ini tidak dapat berikatan dengan pili $\mathrm{P}$, sehingga bakteri dengan jenis pili ini dapat menempel pada urotelium. Selain itu, adanya gangguan pada mekanisme wash out urine mengakibatkan bakteri mudah melakukan replikasi dan menempel pada urotelium. ${ }^{7}$ Beberapa bakteri yang dapat menyebabkan infeksi saluran kemih yaitu Staphylococcus aureus dan Staphylococcus saprophyticus. ${ }^{8}$

Staphylococcus aureus dan Staphylococcus saprophyticus merupakan spesies yang paling sering dijumpai dari genus Staphylococcus. Staphylococcus aureus merupakan patogen utama untuk manusia. Salah satu infeksi berat yang disebabkan Staphylococcus aureus yaitu infeksi saluran kemih. Infeksi ini berasal dari organ lain yang sudah terinfeksi lalu menyebar melalui darah atau secara hematogen menuju ke saluran kemih. Staphylococcus saprophyticus merupakan bakteri koagulase nagatif yang tidak memproduksi eksotoksin. Diketahui menjadi penyebab kedua terbanyak infeksi saluran kemih pada wanita muda. ${ }^{9}$ Berdasarkan hasil penelitian bakteri gram positif dari 100 sampel urin penderita ISK di Medan dari januari hingga desember 2006 didapatkan hasil Staphylococcus aureus 40 strain dan Staphylococcus saprophyticus 18 strain. ${ }^{8}$ Oleh karena itu perlu adanya penelitian terhadap kedua bakteri gram positif tersebut.

Tanaman obat sudah sejak lama digunakan masyarakat Indonesia turun temurun. Salah satu tanaman yang digunakan oleh masyarakat di
Kalimantan Tengah adalah bawang suna (Allium schoenoprasum L). Tanaman ini dikenal masyarakat sebagai sayuran atau pengganti bawang merah. Berdasarkan hasil uji fitokimia, umbi bawang suna (Allium schoenoprasum L) mengandung senyawasenyawa kimia yaitu saponin, alkaloid, flavonoid, tanin, dan steroid. Kandungan senyawa tersebut dapat bekerja sebagai antimikroba atau antibakteri sehingga membuat umbi bawang suna (Allium schoenoprasum L) berpotensi sebagai antibakteri bagi Staphylococcus aureus dan Staphylococcus saprophyticus.

\section{METODE}

\section{Jenis Dan Rancangan Penelitian}

Jenis penelitian ini merupakan penelitian true experimental design. Dimana peneliti dapat mengontrol semua variabel luar yang mempengaruhi jalannya eksperimen. Rancangan yang digunakan dalam penelitian ini yaitu post test-only control group design.

\section{Sampel Dan Teknik Pengambilan Sempel}

Pengambilan sampel dilakukan dengan teknik purposive sampling. Metode ini menggunakan kriteria yang telah dipilih berdasarkan kriteria inklusi dan eksklusi. Sampel diambil menggunakan jarum ose.

Terdapat 7 perlakuan yang digunakan yaitu konsentrasi 20\%, 40\%, 60\%, 80\% dan 100\%, ditambah dengan 1 perlakuan untuk kontrol positif dan 1 perlakuan untuk kontrol negatif, dengan pengulangan sebanyak 4 kali. Jadi didapatkan total sebanyak 56 perlakuan.

\section{Alat dan Bahan Penelitian}

Alat-alat yang akan digunakan pada penelitian ini yaitu: pisau, blender, neraca analitik, kain hitam, toples maserasi, evaporator, batang pengaduk, kertas saring, labu Erlenmeyer, gelas ukur, tabung reaksi, rak tabung, labu ekstraksi, corong, inkubator, kertas saring Kirby-Bauer, aluminiumfoil, Laminar air flow, plastik, kertas sampul, spatula, lidi kapas, autoclave, lemari pendingin, mikro pipet, pipet hisap, cawan petri, bunsen, jarum ose dan jangka sorong.

Bahan-bahan yang digunakan dalam penelitian ini yaitu: umbi Bawang suna (Allium schoenoprasum L) yang didapat dari desa Lunuk Ramba Km.4 Kecamatan Basarang, Kabupaten Kapuas, Kalimantan Tengah, Azitromisin $15 \mathrm{~g}$, etanol 96\%, dimetil sulfoxide (DMSO), Blood Agar, Mueller Hinton Agar, larutan Mc Farland skala 0.5, larutan $\mathrm{NaCl}(0.9 \%)$, Staphylococcus aureus ATCC 25923 dan Staphylococcus saprophyticus ATTC 49453.

\section{Proses Pembuatan Media}

1. Pembuatan Media Blood Agar

Pembuatan media Blood Agar dilakukan dengan menimbang 40 gram blood agar base (Oxoid). Lalu ditambahkan aquades hingga 1,000 $\mathrm{ml}$, kemudian sterilkan medium menggunakan 
autoclave selama 15 menit pada suhu $121^{\circ} \mathrm{C}$. Dinginkan beberapa saat dan tambahkan $7 \%$ darah steril, kemudian dituangkan di atas lapisan dasar cawan petri pada suhu ruangan \pm 30 menit sampai media memadat pada kemiringan $30^{\circ} .{ }^{10}$

2. Pembuatan media Mueller Hinton Agar (MHA) Pembuatan media Mueller Hinton Agar (MHA) dilakukan dengan menimbang bahan sebanyak 38 gram kemudian dilarutkan dalam $1 \mathrm{~L}$ akuades lalu dipanaskan sambil diaduk menggunakan magnestik stirrer hingga homogen. Kemudian media disterilkan dalam autoclave selama 15 menit dengan suhu $121^{\circ} \mathrm{C}$ dan tekanan 1.5 atm. Setelah proses sterilisasi, media dimasukkan kedalam cawan petri sebanyak $15 \mathrm{ml}$ kemudian simpan dalam lemari es. ${ }^{11,12}$

3. Standar Mc. Farland No. 0.5

Standar kekeruhan Mc. Farland dibuat dengan cara mencampurkan $\mathrm{BaCl}_{2} 1 \%$ sebanyak 0.5 $\mathrm{ml}$ dan $\mathrm{H}_{2} \mathrm{SO}_{4} 1 \%$ sebanyak $9.95 \mathrm{ml}$ dalam tabung reaksi dan dikocok hingga homogen. Kekeruhan digunakan sebagai standar kekeruhan suspensi bakteri uji. ${ }^{13}$

\section{HASIL}

Pada penelitian ini digunakan umbi bawang suna (Allium schoenoprasum L) yang telah dipisahkan dengan daun dan akar bawang hingga menyisakan bagian umbinya saja (bagian berwarna putih). Umbi bawang suna (Allium schoenoprasum L) dikeringkan lalu dimaserasi dengan etanol $96 \%$ selama 24 jam, kemudian disaring untuk mendapatkan filtrat. Selanjutnya dilakukan proses pemekatan dan didapatkan ekstrak kental seperti pada tabel.

Tabel 1 Hasil Ekstraksi Umbi Bawang Suna (Allium schoenoprasum $\mathrm{L}$ )

\begin{tabular}{lllll}
\hline $\begin{array}{l}\text { Berat } \\
\text { awal }\end{array}$ & $\begin{array}{l}\text { Berat } \\
\text { simplisia }\end{array}$ & $\begin{array}{l}\text { Hasil } \\
\text { filtrat }\end{array}$ & $\begin{array}{l}\text { Ekstrak } \\
\text { kental }\end{array}$ & Rendemen \\
\hline $8,000 \mathrm{~g}$ & $666.8 \mathrm{~g}$ & $900 \mathrm{ml}$ & $99 \mathrm{~g}$ & $14.847 \%$ \\
\hline
\end{tabular}

Hasil pemeriksaan skrining fitokimia ekstrak etanol umbi bawang suna (Allium schoenoprasum L) didapatkan sebagai berikut.

Tabel 2 Hasil Uji Skrining Fitokimia Umbi Bawang Suna (Allium schoenoprasum L)

\begin{tabular}{lll}
\hline No & Senyawa yang diuji & \multicolumn{1}{c}{ Rata-rata \pm SD } \\
\hline 1. & Saponin $(\%)$ & $14.375 \pm 0.960$ \\
2. & Alkaloid $(\%)$ & $20.103 \pm 0.457$ \\
3. & Flavonoid $(\mathrm{mg} / \mathrm{ml} \mathrm{QE)})$ & $19.000 \pm 0.661$ \\
4. & Steroid $(\mathrm{mg} / \mathrm{ml})$ & $19.258 \pm 0.103$ \\
5. & Tannin $(\mathrm{mg} / \mathrm{ml} \mathrm{QE)}$ & $1.205 \pm 0.30$ \\
\hline & Pada penelitian ini & dilakukan pengujian
\end{tabular}
aktivitas antibakteri ekstrak umbi bawang suna (Allium schoenoprasum L) terhadap pertumbuhan bakteri Staphylococcus aureus dan Staphylococcus saprophyticus dengan metode difusi cakram Kirby-
Bauer. Perbandingan penelitian dilakukan menggunakan berbagai konsentrasi ekstrak umbi bawang suna (Allium schoenoprasum L) (20\%, 40\%, $60 \%, 80 \%$, dan $100 \%$ ), penelitian ini juga menggunakan antibiotik Azitromisin sebagai kontrol positif (+) dan DMSO sebagai kontrol negatif (-). Hasil pengukuran diameter zona hambat ekstrak umbi bawang suna (Allium schoenoprasum L) terhadap bakteri Staphylococcus aureus tercantum dalam gambar 1 dan terhadap bakteri Staphylococcus saprophyticus dalam gambar 2.

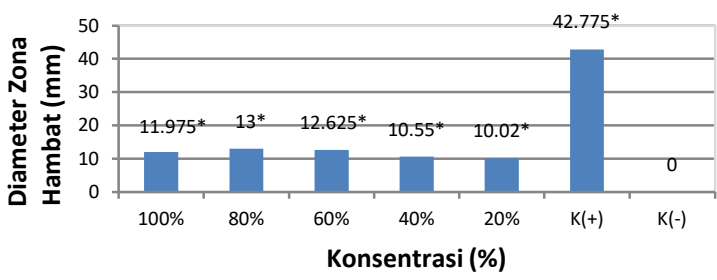

Keterangan: *terdapat perbedaan bermakna $(p<0.05)$ dengan kontrol negatif

Gambar 1

Menunjukan hasil pengukuran diameter zona hambat yang terbentuk pada media Mueller Hinton Agar (MHA) pada bakteri Staphylococcus aureus.

Setelah didapatkan data besaran zona bening pada masing-masing konsentrasi dan kontrol dilakukan uji normalitas. Pada uji normalitas Shapiro-wilk di dapatkan $\mathrm{p}=<0.05$. Hal ini menunjukan bahwa data tidak terdistribusi normal. Selanjutnya dilakukan uji homogenitas untuk mengetahui data homogen atau tidak.

Pada uji homogenitas Levene Test di dapatkan $\mathrm{p}<0.05$ ( $\mathrm{p}>0.05$ ) pada bakteri Staphylococcus aureus. Hal ini menunjukan bahwa data tidak homogen. Data yang didapat dari uji normalitas dan uji homogenitas menunjukan bahwa data tidak terdistribusi normal dan data tidak homogen sehingga syarat One Way Anova tidak terpenuhi, yaitu data terdistribusi normal dan varian data homogen. Maka digunakan uji nonparametrik Kruskal Wallis.

Pada uji Kruskal Wallis didapatkan $\mathrm{p}=0.001$ ( $\mathrm{p}<0.05$ ). Hal ini menunjukan bahwa diameter zona hambat pada masing-masing konsentrasi memiliki perbedaan bermakna, sehingga dilanjutkan menggunakan analisis Post Hoc Mann Whitney. 
Tabel 3 Hasil uji Post Hoc Mann Whitney Membandingkan Tiap Pasang Perlakuan Ekstrak Etanol Umbi Bawang Suna (Allium schoenoprasum L) Pada Bakteri

\begin{tabular}{|c|c|c|c|c|c|c|c|}
\hline \multicolumn{8}{|c|}{ Probabilitas } \\
\hline $\begin{array}{l}\text { Perlak } \\
\text { uan }\end{array}$ & $\mathrm{K}(+)$ & $\begin{array}{l}100 \\
\%\end{array}$ & $80 \%$ & $60 \%$ & $40 \%$ & $\begin{array}{l}20 \\
\%\end{array}$ & $\mathrm{~K}(-)$ \\
\hline $\mathrm{K}(+)$ & & $\begin{array}{l}0.02 \\
1^{\mathrm{b}}\end{array}$ & $\begin{array}{l}0.02 \\
1^{\mathrm{b}}\end{array}$ & $\begin{array}{l}0.02 \\
0^{b}\end{array}$ & $\begin{array}{l}0.02 \\
0^{\mathrm{b}}\end{array}$ & $\begin{array}{l}0 . \\
02 \\
1^{\mathrm{a}}\end{array}$ & $\begin{array}{l}0.0 \\
14^{\mathrm{b}}\end{array}$ \\
\hline $100 \%$ & $\begin{array}{l}0.0 \\
21^{\mathrm{b}}\end{array}$ & & $\begin{array}{l}1.00 \\
0^{\mathrm{a}}\end{array}$ & $\begin{array}{l}0.55 \\
4^{\mathrm{a}}\end{array}$ & $\begin{array}{l}0.02 \\
0^{\mathrm{b}}\end{array}$ & $\begin{array}{l}0 . \\
02 \\
1^{\mathrm{a}}\end{array}$ & $\begin{array}{l}0.0 \\
14^{\mathrm{b}}\end{array}$ \\
\hline $80 \%$ & $\begin{array}{l}0.0 \\
21^{\mathrm{b}}\end{array}$ & $\begin{array}{l}1.00 \\
0^{\mathrm{a}}\end{array}$ & & $\begin{array}{l}0.77 \\
2^{\mathrm{a}}\end{array}$ & $\begin{array}{l}0.05 \\
8^{a}\end{array}$ & $\begin{array}{l}0 . \\
05 \\
9^{a}\end{array}$ & $\begin{array}{l}0.0 \\
14^{\mathrm{b}}\end{array}$ \\
\hline $60 \%$ & $\begin{array}{l}0.0 \\
20^{\mathrm{b}}\end{array}$ & $\begin{array}{l}0.05 \\
4^{\mathrm{a}}\end{array}$ & $\begin{array}{l}0.77 \\
2^{\mathrm{a}}\end{array}$ & & $\begin{array}{l}0.01 \\
9^{\mathrm{b}}\end{array}$ & $\begin{array}{l}0 . \\
02 \\
0^{\mathrm{b}}\end{array}$ & $\begin{array}{l}0.0 \\
13^{\mathrm{b}}\end{array}$ \\
\hline $40 \%$ & $\begin{array}{l}0.0 \\
20^{\mathrm{b}}\end{array}$ & $\begin{array}{l}0.02 \\
0^{\mathrm{b}}\end{array}$ & $\begin{array}{l}0.05 \\
8^{a}\end{array}$ & $\begin{array}{l}0.01 \\
9^{b}\end{array}$ & & $\begin{array}{l}0 . \\
56 \\
1^{\mathrm{a}}\end{array}$ & $\begin{array}{l}0.0 \\
13^{\mathrm{b}}\end{array}$ \\
\hline $20 \%$ & $\begin{array}{l}0.0 \\
21^{\mathrm{b}}\end{array}$ & $\begin{array}{l}0.02 \\
1^{\mathrm{b}}\end{array}$ & $\begin{array}{l}0.05 \\
9^{a}\end{array}$ & $\begin{array}{l}0.02 \\
0^{\mathrm{b}}\end{array}$ & $\begin{array}{l}0.56 \\
1^{\mathrm{a}}\end{array}$ & & $\begin{array}{l}0.0 \\
14^{\mathrm{b}} \\
\end{array}$ \\
\hline $\mathrm{K}(-)$ & $\begin{array}{l}0.0 \\
14^{\mathrm{b}}\end{array}$ & $\begin{array}{l}0.01 \\
4^{b}\end{array}$ & $\begin{array}{l}0.01 \\
4^{b}\end{array}$ & $\begin{array}{l}0.01 \\
3^{\mathrm{b}}\end{array}$ & $\begin{array}{l}0.01 \\
3^{\mathrm{b}}\end{array}$ & $\begin{array}{l}0 . \\
01 \\
4^{b}\end{array}$ & \\
\hline
\end{tabular}

Keterangan:

a : tidak terdapat berbeda bermakna $(p>0.05)$

$\mathrm{b}$ : terdapat perbedaan bermakna $(\mathrm{p}<0.05)$

Pada uji yang dilakukan dengan pembanding kontrol positif dan kontrol negatif terhadap bakteri Staphylococcus aureus didapatkan pada konsentrasi $20 \%$ hingga $100 \%$ nilai p (Asymp.Sig) $<0.05$, sehingga dapat disimpulkan bahwa pada kelima konsentrasi tersebut memiliki daya hambat yang bermakna secara statistik terhadap bakteri uji. Data yang memiliki signifikansi $\mathrm{p}>0.05$ yang menunjukan tidak ada perbedaan bermakna terdapat pada perbandingan konsentrasi $100 \%$ dan $80 \%$, konsentrasi $100 \%$ dan $60 \%$, konsentrasi $80 \%$ dan $60 \%$, konsentrasi $80 \%$ dan $40 \%$, konsentrasi $80 \%$ dan $20 \%$, dan konsentrasi $40 \%$ dan $20 \%$. Hal ini dikarenakan zona hambat yang dihasilkan oleh kedua konsentrasi memiliki selisih yang kecil.

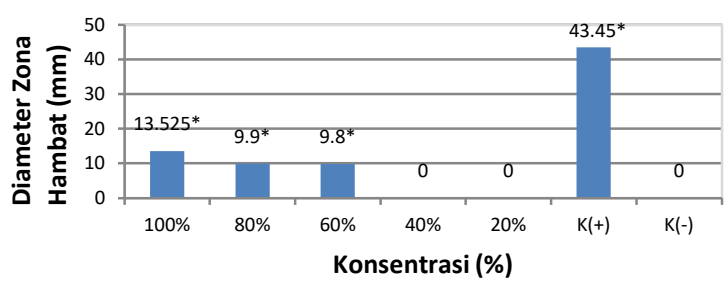

Gambar 2
Menunjukan hasil pengukuran diamter zona hambat yang terbentuk pada media Mueller Hinton Agar (MHA) pada bakteri Staphylococcus Saprophyticus.

Setelah didapatkan besaran data zona bening pada masing-masing konsentrasi maka dilakukan uji normalitas untuk mengetahui apakah data terdistribusi normal atau tidak. Pada uji normalitas Shapiro-wilk di dapatkan $\mathrm{p}=<0.01 \quad(\mathrm{p}<0.05)$. Sehingga dapat disimpulkan data tidak terdistribusi normal.

Selanjutnya dilakukan uji homogenitas untuk mengetahui data homogen atau tidak. Pada uji homogenitas Levene Test di dapatkan $\mathrm{p}<0.05$ ( $\mathrm{p}>0.05$ ). Hal ini menunjukan bahwa data tidak homogen. Data yang didapat dari uji normalitas dan uji homogenitas menunjukan bahwa data tidak terdistribusi normal dan data tidak homogen sehingga syarat One Way Anova tidak terpenuhi, yaitu data terdistribusi normal dan varian data homogen. Maka digunakan uji nonparametrik Kruskal Wallis.

Berdasarkan hasil analisis data non parametrik Kruskal-Wallis didapatkan nilai $\mathrm{p}=<0.001(\mathrm{p}<0.05)$ pada bakteri Staphylococcus saprophyticus, maka dapat diambil kesimpulan bahwa terdapat perbedaan bermakna diameter zona hambat antara ketujuh kelompok perlakuan pada bakteri uji, sehingga selanjutnya dilakukan uji analisis Post Hoc Mann Whitney untuk membandingkan tiap perlakuan ekstrak etanol umbi bawang suna (Allium schoenoprasum L) dari tiap konsentrasi yang berbeda dengan kontrol positif dan negatif.

Tabel 4 Hasil Uji Non Parametrik Mann Whitney Membandingkan Tiap Pasang Perlakuan Ekstrak Etanol Umbi Bawang Suna (Allium schoenoprasum L) Terhadap Bakteri Staphylococcus saprophyticus.

Probabilitas

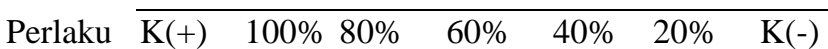

\begin{tabular}{|c|c|c|c|c|c|}
\hline $\mathrm{K}(+)$ & & $0.0210 .021^{b}$ & $0.020^{\mathrm{b}}$ & $0.014^{\mathrm{b}} 0.014^{\mathrm{b}}$ & $\begin{array}{l}0.014 \\
\mathrm{~b}\end{array}$ \\
\hline $100 \%$ & $0.021^{b}$ & $0.059^{a}$ & $0.020^{\mathrm{b}}$ & $0.014^{\mathrm{b}} 0.014^{\mathrm{b}}$ & $\begin{array}{l}0.014 \\
\mathrm{~b}\end{array}$ \\
\hline $80 \%$ & $0.021^{\mathrm{b}}$ & $\begin{array}{l}0.059 \\
\mathrm{a}\end{array}$ & $0.020^{\mathrm{b}}$ & $0.014^{\mathrm{b}} 0.014^{\mathrm{b}}$ & $\begin{array}{l}0.014 \\
\mathrm{~b}\end{array}$ \\
\hline $60 \%$ & $0.020^{\mathrm{b}}$ & $0.0200 .020^{\mathrm{b}}$ & & $0.013^{b} 0.013^{b}$ & $\begin{array}{l}0.013 \\
\mathrm{~b}\end{array}$ \\
\hline $40 \%$ & $0.014^{\mathrm{b}}$ & $\begin{array}{l}0.0140 .014^{\mathrm{b}} \\
\mathrm{b}\end{array}$ & $0.013^{\mathrm{b}}$ & $1.000^{\mathrm{a}}$ & $\begin{array}{l}1.000 \\
\mathrm{a}\end{array}$ \\
\hline $20 \%$ & $0.014^{\mathrm{b}}$ & $\begin{array}{l}0.0140 .014^{\mathrm{b}} \\
\mathrm{b}\end{array}$ & $0.013^{b}$ & $1.000^{\mathrm{a}}$ & 1.000 \\
\hline $\mathrm{K}(-)$ & $0.014^{\mathrm{b}}$ & $\begin{array}{l}0.0140 .014^{b} \\
b\end{array}$ & $0.013^{\mathrm{b}}$ & $1.000^{\mathrm{a}} 1.000^{\mathrm{a}}$ & \\
\hline
\end{tabular}

Keterangan:

$a$ : tidak terdapat perbedaan bermakna $(p>0.05)$

$\mathrm{b}:$ terdapat perbedaan bermakna $(\mathrm{p}<0.05)$ 
Pada uji yang dilakukan dengan pembanding kontrol negatif pada konsentrasi $20 \%$ dan $40 \%$ tidak terdapat perbedaan bermakna. Pada uji yang dilakukan dengan pembanding kontrol negatif digunakan untuk menilai daya antibakteri secara statistik. Pada uji yang dilakukan dengan pembanding kontrol positif digunakan untuk menilai besarnya potensi antibakteri pada masing-masing konsentrasi secara statistik. $^{14}$ Dapat disimpulkan bahwa pada konsentrasi 100\%, 80\%, dan $60 \%$ memiliki daya hambat yang bermakna secara statistik terhadap bakteri uji, sementara konsentrasi $40 \%$ dan $20 \%$ tidak memiliki daya hambat yang bermakna secara statistik terhadap bakteri uji. Pada perbandingan antara konsentrasi didapatkan signifikansi $\mathrm{p}>0.05$ yang menunjukan tidak ada perbedaan bermakna terdapat pada perbandingan konsentrasi $100 \%$ dan $80 \%$ dan konsentrasi $40 \%$ dan $20 \%$. Hal ini dikarenakan zona hambat yang dihasilkan oleh kedua konsentrasi memiliki selisih yang kecil.

Penelitian ini menggunakan umbi bawang suna (Allium schoenoprasum L) untuk diekstrak lalu dilakukan uji aktivitas antibakteri pada bakteri Staphylococcus aureus dan Staphylococcus saprophyticus. Pada penelitian ini didapatkan rendemen ekstrak sebanyak $14.847 \%$. Pada penelitian sebelumnya didapatkan rendemen ekstrak sebesar $16 \% .{ }^{15}$ Pada saat menggunakan rotary evaporation pada proses maserasi ekstrak, peneliti menggunakan suhu $28^{\circ} \mathrm{C}$. Menurut Moestofa, ekstraksi lebih cepat dilakukan pada suhu tinggi, tetapi hal ini akan menyebabkan beberapa kompenen yang terdapat dalam tumbuhan mengalami kerusakan. Selain itu, pada suhu yang tinggi mengakibatkan sebagian etanol menguap sehingga jumlah pelarut berkurang dan tidak mencukupi untuk mengekstrak bahan sehingga jumlah rendemen menjadi berkurang. ${ }^{16}$

Penelitian ini menggunakan kontrol negatif DMSO. DMSO (dimethylsulfoxide) merupakan pelarut organik dan tidak bersifat bakterisidal serta dapat melarutkan hampir seluruh senyawa polar dan nonpolar sehingga DMSO dapat digunakan sebagai pengencer untuk memperoleh ekstrak dengan kadar konsentrasi tertentu. ${ }^{17}$ Pada penelitian ini peneliti tidak menggunakan Aquades sebagai pengencer dikarenakan penggunaan aquades dapat memungkinkan terjadinya reaksi hidrolisa. ${ }^{18}$ Menurut Wiryowidagdo allicin bersifat tidak stabil dan dapat teurai pada saat penyulingan atau dihidrolisis dengan air ${ }^{19}$ sehingga untuk menjaga kandungan yang terdapat didalam umbi bawang suna peneliti menggunakan pengencer DMSO.

Pada penelitian ini, sebelumnya digunakan antibiotik trimethoprim-sulfamethoxazole sebagai kontrol positif. Trimethoprim-sulfamethoxazole merupakan salah satu antibiotik yang digunakan secara epiris pada ISK. $^{20}$ Berdasarkan CLSI trimethoprimsulfamethoxazole, merupakan antibiotik golongan A terhadap bakteri Staphylococcus, dimana dikatakan sensitif $\geq 16 \mathrm{~mm}$, intermediet $10-15 \mathrm{~mm}$, dan resisten $\leq 0 \mathrm{~mm} .{ }^{21}$ Berdasarkan hasil penelitian didapatkan bahwa antibiotik trimethoprim-sulfamethoxazole resisten terhadap bakteri Staphylococcus sapropyticus. Dimana tidak terbentuk zona bening disekitar kertas cakram. Hal ini menunjukan bahwa adanya fenomena pola kuman dan resistensi antibiotik, yang dapat berubah dari waktu ke waktu yang disebabkan karena kebijakan dalam penggunaan dan pemilihan jenis antibiotik yang berbeda-beda dan lamanya penggunaan obat, selain itu dapat disebabkan oleh mutasi genetik, pada mikroorganisme penyebab infeksi. Hal ini sesuai dengan penelitian yang dilakukan oleh Lindayanti dkk, di RS H. Adam Malik Medan, dimana didapatkan pola resistensi trimethoprim-sulfamethoxazole sebesar $84 \% .^{22}$ Penelitian yang sama dilakukan oleh Sofia di RS PKU Muhammadiyah Surakarta, dimana didapatkan pola resistensi sebesar $50 \%$. Terjadinya resistensi bakteri ini dikarenakan berkurangnya permeabilitas sel, kelebihan dihidrofolat reduktase, perlawanan juga dapat muncul dengan mutasi karena plasmid tahan terhadap reduktase dihidrofolat yang menghasilkan target baru sehingga tidak sensitif terhadap obat. ${ }^{23}$ Terdapatnya resistensi kontrol positif Treimethoprimsulfamethoxazole terhadap bakteri uji Staphylococcus saprophyticus menjadi alasan peneliti untuk mengganti antibiotik kontrol positif berdasarkan panduan CLSI menjadi Azitromisin. Kontrol positif azitromisin menunjukan adanya zona bening yang diukur menggunakan jangka sorong dengan rata-rata hasil pengukuran $42.7750 \mathrm{~mm}$ pada bakteri Staphylococcus aureus dan $43.4500 \mathrm{~mm}$ pada bakteri Staphylococcus saprophyticus. Berdasarkan CLSI, zona hambat azitromisin dikatakan sensitif jika $\geq 18 \mathrm{~mm}$, intermediet 14-17 mm dan resisten $\leq 3 \mathrm{~mm} .{ }^{21} \mathrm{Hal}$ ini menunjukan bahwa Azitromisin masih sensitif terhadap bakteri Staphylococcus aureus dan Staphylococcus saprophyticus. Azitromisin bekerja dengan mekanisme menghambat biosintesis protein pada ribosom $50 \mathrm{~S}$. Penetrasi intraseluler sangat besar pada 24 jam pertama dan berlanjut hingga 72 jam pada fibroblast manusia. ${ }^{24}$

Hasil uji aktivitas antibakteri pada penelitian ini menunjukan zona hambat pertumbuhan bakteri Staphylococcus aureus terdapat pada konsentrasi $100 \%$, $80 \%$, 60\%, $40 \%$ dan $20 \%$ dan pada bakteri Staphylococcus saprophyticus terdapat pada konsentrasi $100 \%, 80 \%$, dan $60 \%$.

Menurut Amrie, daya hambat yang dihasilkan oleh bahan antimikroba akan semakin tinggi apabila konsentrasinya juga tinggi. ${ }^{25}$ Konsentrasi ekstrak etanol umbi bawang suna (Allium schoenoprasum L) yang semakin meningkat memberikan daya hambat yang semakin besar pula, karena semakin banyaknya ekstrak yang bersifat antibakteri terakumulasi pada media tumbuh sehingga semakin dapat mengganggu proses pertumbuhan bakteri uji. Pada konsentrasi esktrak 100\% terhadap bakteri Staphylococcus aureus zona hambat yang terbentuk mengalami penurunan dari konsentrasi 
sebelumnya. Menurut Handajani dan Purwoko hal ini mungkin disebabkan oleh daya difusi ekstrak kedalam media yang berkurang. Penurunan daya difusi mungkin disebabkan semakin tingginya konsentrasi ekstrak maka semakin rendah kelarutannya (mengental seperti gel). ${ }^{14}$ Selain itu ekstrak etanol umbi bawang suna (Allium schoenoprasum L) pada konsentrasi $20 \%$ dan $40 \%$ terhadap bakteri Staphylococcus saprophyticus menunjukkan tidak terbentuk zona hambat, yang mungkin disebabkan oleh konsentrasi yang terlalu kecil sehingga belum dapat menyebabkan terjadinya aktivitas antibakteri. Menurut Siswandono dan Soekardjo, konsentrasi suatu bahan yang berfungsi sebagai antibakteri merupakan salah satu faktor penentu besar kecil kemampuanya dalam menghambat bakteri yang diuji. ${ }^{14}$

Menurut David dan Stout, zona hambat yang terbentuk $\geq 20 \mathrm{~mm}$ dianggap memiliki aktivitas daya hambat sangat kuat, 10-20 mm dinyatakan memiliki aktivitas daya hambat yang kuat, 5-10 mm dinyatakan memiliki aktivitas daya hambat yang sedang dan $\leq 5 \mathrm{~mm}$ dinyatakan memiliki aktivitas daya hambat yang lemah. ${ }^{26}$ Kriteria aktivitas daya hambat dari ekstrak etanol umbi bawang suna (Allium schoenoprasum L) pada rata-rata konsentrasi 100\%, 80\%, 60\%, 40\% dan $20 \%$ terhadap bakteri Staphylococcus aureus dianggap memiliki aktivitas daya hambat kuat dan terhadap bakteri Staphyloccocus saprophyticus pada rata-rata konsentrasi $100 \%$ dianggap memiliki aktivitas daya hambat kuat, rata-rata konsentrasi $80 \%$ dan $60 \%$ dianggap memiliki aktivitas daya hambat sedang dan rata-rata konsentrasi $40 \%$ dan $20 \%$ dianggap memiliki aktivitas daya hambat yang lemah. Berdasarkan tabel CLSI untuk antibiotik Azitromisin, aktivitas daya hambat umbi bawang suna (Allium schoenoprasum L) dikategorikan resisten terhadap bakteri uji.

Terbentuknya zona hambat pada masingmasing konsentrasi ekstrak etanol umbi bawang suna (Allium schoenoprasum L) dipengaruhi oleh zat-zat aktif yang terdapat didalamnya yaitu saponin, alkaloid, flavonoid, steroid dan tannin yang masing-masing memiliki aktivitas antibakteri yang berbeda.

Pada penelitian ini didapatkan jumlah alkaloid lebih tinggi dari jumlah saponin. Bawang putih (Allium sativum L) yang berasal dari suku liliaceae yang sama dengan bawang suna (Allium schoenoprasum L) kaya akan kandungan alkaloid dan merupakan golongan zat sekunder yang terbesar. ${ }^{27} \mathrm{Hal}$ ini memungkinkan umbi bawang suna juga memiliki alkaloid yang lebih tinggi dibandingkan saponin. Berdasarkan penelitian sebelumnya kandungan antioksidan dalam bawang putih didapatkan kandungan flavonoid memiliki peranan utama sebagai senyawa yang bertanggung jawab dalam aktivitas antioksidan. ${ }^{28}$ Hal ini juga memungkinkan umbi bawang suna juga memiliki kandungan flavonoid yang tinggi.

Saponin merupakan suatu glikosida alami yang terikat dengan steroid atau triterpena dan di temukan dalam berbagai tanaman. Mekanisme antibakteri saponin yaitu dengan menyebabkan kebocoran protein dan enzim dari dalam sel. Hal ini dikarenakan permukaan saponin mirip dengan detergent yang menyebabkan penurunan tegangan permukaan dinding dan merusak permeabilitas membran sel bakteri. ${ }^{29,30}$

Alkaloid merupakan senyawa metabolit sekunder dengan atom nitrogen terbanyak dan berfungsi sebagai obat dan aktivator kuat bagi sel imun yang dapat menghancurkan bakteri, virus, jamur, dan sel kanker. Mekanisme antibakteri alkaloid yaitu mengganggu komponen penyusun peptidokglikan bakteri agar lapisan dinding sel tidak terbentuk sempurna sehingga terjadi kematian sel. Mekanisme lain antibakteri alkaloid diketahui sebagai interkelator DNA dan menghambat enzim topoisomerase sel bakteri. ${ }^{31,32}$

Flavonoid adalah suatu kelompok senyawa metabolit sekunder yang terbesar dan banyak di temukan di dalam tumbuhan. Terdapat tiga mekanisme kerja flavonoid sebagai antimikroba yaitu, menghambat sintesis asam nukleat, menghambat fungsi membran sel, dan menghambat metabolisme energi. ${ }^{33}$

Steroid adalah senyawa bahan alam yang terdiri dari kerangka karbon dan terdiri atas tiga lingkar enam perhidro fenantren dan terfusi menjadi suatu lingkar lima. Mekanisme steroid sebagai antibakteri yaitu dengan merusak membran lipid sehingga liposom mengalami kebocoran. Karena memiliki sifat yang permeabel terhadap senyawa-senyawa lipofilik, steroid menyebabkan integritas membran fosfolipid menurun dan struktur membran sel terganggu sehingga mengalami lisis dan rapuh. ${ }^{34,35}$

Tannin merupakan senyawa kimia yang tergolong dalam senyawa polifenol. Mekanisme antibakteri tanin yaitu menghambat enzim reverse transkriptase dan DNA topoisomerase sehingga sel bakteri tidak dapat terbentuk. Selain itu, tanin juga dapat mengkerutkan membran sel atau dinding sel yang dapat menganggu permeabilitas sel bakteri. Tannin diketahui menghambat pembentukan polipeptida dinding sel, sehingga pembentukan dinding sel menjadi kurang sempurna dan membuat bakteri mati karena lisis. ${ }^{36,37,38}$

Menurut Pongsak dan Parichat, lokio (Allium schoenoprasum L) memiliki kandungan diallyl sulfide sebanyak 42.3\%, diallyl trisulfide dan diallyl tetrasulfide yang dapat menghambat bakteri Staphylococcus aureus. Kandungan-kandungan tersebut merupakan dekomposisi lanjut dari komponen sulfur dan merupakan turunan dari allicin. Komponen tersebut hanya akan muncul melalui proses pemotongan atau dihancurkan. Pemotongan dan penghancuran akan mengaktifkan enzim allinase yang akan memetabolisme aliin menjadi alicin. Alicin merupakan senyawa yang tidak stabil dan dalam waktu beberapa jam dapat dimetabolisme menjadi sulfur lain seperti vinyldithiines dan diallyl disulfie (ajoene) yang juga memiliki aktivitas antibakteri akan tetapi lebih lemah. ${ }^{39,40}$ 


\section{KESIMPULAN}

Berdasarkan hasil dan pembahasan dalam penelitian dapat ditarik kesimpulan sebagai berikut :

1. Ekstrak etanol umbi bawang suna (Allium schoenoprasum L) memiliki aktivitas antibakteri terhadap Staphylococcus aureus.

2. Ekstrak etanol umbi bawang suna (Allium schoenoprasum L) memiliki aktivitas antibakteri terhadap Staphylococcus saprophyticus pada konsentrasi $100 \%$, 80\% dan 60\%.

\section{UCAPAN TERIMA KASIH}

Kepada Fakultas Kedokteran Universitas Palangka Raya yang sudah memberikan dukungan dalam pembuatan artikel ini dan memberikan izin penggunaan Laboratorium Mikrobiologi Fakultas Kedokteran Universitas Palangka Raya.

\section{DAFTAR PUSTAKA}

1. Musdalipah M. Identifikasi Drug Related Problem (DRP) Pada Pasien Infeksi Saluran Kemih Di Rumah Sakit Bhayangkara Kendari. Jurnal Kesehatan. 2018;11(1):39-50.

2. Sholihah AH. Analisis Faktor Resiko Kejadian Infeksi Saluran Kemih (ISK) oleh Bakteri Uropatogen di Puskesmas Ciputat dan Pamulung pada Agustus-Oktober 2017 [Skripsi]. Jakarta: Universitas Islam Negeri Syarif Hidayatullah; 2017.

3. Foxman B. Urinary tract infection syndromes. Occurrence, recurrence, bacteriology, risk factors, and disease burden. Infection Disease Clinical North America [Internet]. 2014;28(1):1-13. Available from: http://dx.doi.org/10.1016/j.idc.2013.09.003

4. Dapertemen Kesehatan RI. Survei Demografi Dan Kesehatan Indonesia. Jakarta : Depkes RI; 2014.

5. RSUD dr Doris Sylvanus. Pelaporan Data Rekam Medis 2014-2018. Palangkaraya: Pemerintah Provinsi Kalimantan Tengah;

6. Syukri M. Penanganan Infeksi Saluran Kemih. Jurnal Kedokteran Syiah Kuala. 2008;8(1):61-6.

7. Purnomo BB. Dasar-Dasar Urologi edisi ke 3. 3rd ed. Malang: CV Sagung Seto; 2016.

8. Anwar R. Bakteri Gram-Positif dari Air Kemih. Laporan Kasus Majalah Kedokteran Nusantara. 2008;41(1):36.

9. Jawetz, Melnick, Adelberg. Mikrobiologi Kedokteran. 25th ed. Adityaputri A, editor. Jakarta: EGC; 2014.

10. Mudatsir. Penggunaan Darah Kadarluarsa Sebagai Media Isolasi dan Identifikasi Streptococcus faecalis. Bagian Mikrobiologi Fakultas Kedokteran Universitas Syiah Kuala. 2010;

11. Hudaya A, Radiastuti N, Sukandar D, Djajanegara I. Uji Aktivitas Antibakteri Ekstrak Air Bunga Kecombrang. 2014;7(April):9-15.

12. Sahrijanna A. Uji Resistensi Staphylococcus aureus Terhadap Antibiotik, Amoxillin, Tetracyclin dan Propolis. Ilmu Alam dan Lingkung. 2017;8(16):527.

13. Mufidah N. Pengaruh Pemberian Tepung Lumbricus rubellus Terhadap Gambaran Histologi Hepar Dan Aktivitas Antioksidan Pada Serum Darah Rattus novergicus Yang Terinfeksi Salmonella typhi [SKRIPSI]. Malang: Universitas Islam Negeri Maulana Malik Ibrahim Malang; 2011.

14. Candrasari A, Romas MA, Hasbi M, Astuti OR. Uji Daya Antibakteri Ekstrak Etanol Daun Sirih Merah (Piper Crocatum Ruiz \& Pav .) Terhadap Pertumbuhan Staphylococcus aureus ATCC 6538, Eschericia coli ATCC 11229 Dan Candida Albicans ATCC 10231 Secara In Vitro. 2012;4:916.

15. Palar MWP. Pengaruh Ekstrak Etanol Umbi Bawang Suna (Allium schoenoprasum L) Terhadap Penurunan Kadar Glukosa Darah Tikus Putih Galur Wistar (Rattus norvegicus) Yang Diinduksi Streptozotocin [SKRIPSI]. Palangka Raya: Universitas Palangka Raya;

16. Kawiji, Khasanah LU, Utami R, Aryani NT. Ekstraksi Maserasi Oleoresin Daun Jeruk Purut (Citrus hystrix DC): Optimasi Rendemen Dan Pengujian Karakteristik Mutu. Agritech. 2015;35(2):178-84.

17. Assidqi K, Tjahjaningsih W, Sigit S. Potensi Ekstrak Daun Patikan Kebo (Euphorbia hirta) Sebagai Antibakteri Terhadap Aeromonas hydrophila Secara In Vitro. Journal of Marine and Coastal Science. 2012;113-24.

18. Raharja S, Suparno O, Mangunwidjaja D. Penambahan pelarut organik pada media untuk hidrolisis enzimatik minyak ikan menggunakan lipase dari Aspergillus niger. 2012;(December).

19. Yuniastuti K. Ekstraksi Dan Identifikasi Komponen Sulfida Pada Bawang Putih (Allium sativum) [SKRIPSI]. Semarang: Universitas Negeri Semarang; 2006.

20. Pardede SO. Infeksi pada Ginjal dan Saluran Kemih Anak: Manifestasi Klinis dan Tata Laksana. 2018;19(6).

21. Clinical and Laboratory Standards Institut. M100 
performance standards for antimicrobial Susceptibility Testing. Clinical and Laboratory Standards Institut. 2018. 296 p.

22. Lubis AR. Pola resistensi antimikroba pada infeksi saluran kemih yang disebabkan oleh bakteri penghasil ESBL dan non-ESBL. Majalah Kedokteran Nusantara. 47(2):77-81.

23. Pradani SA. Pola Kuman Dan Resistensi Bakteri Terhadap Antibiotik Pada Penderita Infeksi Saluran Kemih (ISK) Di Instalasi Rawat Inap Rumah Sakit PKU Muhammadiyah Surakarta Periode FebruariMaret Tahun 2016 [SKRIPSI]. 2016;

24. Lalak NJ, Morris DL. Azithromycin Clinical Pharmacokinetics. 1993;25(5):370-4.

25. Trisia A, Philyria R, Toemon AN. Uji Aktivitas Antibakteri Ekstrak Etanol Daun Kalanduyung (Guazuma ulmifolia Lam.) Terhadap Pertumbuhan Staphyloccoccus Aureus Dengan Metode Difusi Cakram ( Kirby-Bauer). 2018;17(2):136-43.

26. Lingga AR, Pato U, Rossi E. Uji Antibakteri Ekstrak Batang Kecombrang (Nicolaia speciosa Horan) Terhadap Staphylococcus aureus dan Escherichia coli. JOM Faperta. 2016;2(2).

27. Chehama M. Formulasi Sediaan Sabun Padat Ekstrak Etanol Bawang Putih (Allium sativum L.) Dan Uji Aktivitas Antibakteri Terhadap Propionibacterium acnes Dan Staphylococcus epidermidis [SKRIPSI]. Purwokerto: Universitas Muhammadiyah Purwokerto; 2016.

28. Prasonto D, Riyanti E, Gartika M. Uji Aktivitas Antioksidan Ekstrak Bawang Putih (Allium sativum). ODONTO Dent J. 2017;4(2):122.

29. Arif R, Wardatun S, Weandarlina IY. Isolasi Dan Identifikasi Senyawa Saponin Ekstrak Metanol Daun. Jurnal Farmasi. 2008;3-8.

30. Upa G, Ali A, Purnamasari Y. Uji Aktivitas Antibakteri Ekstrak Etanol Bawang Putih (Allium sativum) terhadap Pertumbuhan Bakteri Salmonella typhii dan Shigella dysenteriae. Medula. 2017;4(April).

31. Fitriani A. Aktivitas Alkaloid Ageratum conyzoides L . terhadap Pertumbuhan Bakteri Staphylococcus aureus secara in vitro. Universitas Pendidikan Indonesia. 2014;(Mic).

32. Rijayanti RP. Uji Aktivitas Antibakteri Ekstrak Etanol Daun Mangga Bacang (Mangifera foetida L.) Terhadap Staphylococcus aureus secara In Vitro [SKRIPSI]. 2014.

33. Panche AN, Diwan AD, Chandra SR. Flavonoids: an overview. Journal Nutrition Science. 2016;5:115.
34. Narsudin, Wahyono, Mustofa, Susidarti R. Isolasi Senyawa Steroid Dari Kukit Akar Senggugu. Ilmu Farmasi. 2017;6(3):2-9.

35. Sudarmi K, Darmayasa IBG, Muksin IK. Uji Fitokimia Dan Daya Hambat Ekstrak Daun Juwet (Syzygium cumini) Terhadap Pertumbuhan Escherichia coli Dan Staphylococcus aureus ATCC. SIMBIOSIS Jurnal Biology Science. 2017;5(2):47.

36. Sujarnoko TU. Studi Meta-Analisis Efek Senyawa Metabolit Sekunder Tanin Terhadap Kualitas Silase [SKRIPSI]. Bogor : Institut Pertanian Bogor; 2012.

37. Cut Nuria M, Faizatun A, Sumantri. Uji Aktivitas Antibakteri Ekstrak Etanol Daun Jarak Pagar (Jatropha curcas L) Terhadap Bakteri Staphylococcus aureus ATCC 25923, Escherichia coli ATCC 25922, Dan Salmonella typhi ATCC 1408. Mediagro. 2009;5(2):26-37.

38. Sholikah, ANL. Isolasi Senyawa Steroid Dari Fraksi Petroleum Eter Hasil Hidrolisis Ekstrak Metanol Alga Merah (Eucheuma spinosum) Menggunakan Metode Kromatografi Kolom [SKRIPSI]. Malang: Universitas Islam Negeri Maulana Malik Ibrahim Malang; 2016.

39. Rattanachaikunsopon P, Phumkhachorn P. Diallyl Sulfide Content and Antimicrobial Activity against Food-Borne Pathogenic Bacteria of Chives (Allium schoenoprasum). 2008;72(11):2987-91.

40. Hernawan U. Review: Senyawa Organosulfur Bawang Putih (Allium sativum L.) dan Aktivitas Biologinya. Jurnal Biofarmasi UNS. 2003;(Agustus). 